\title{
Wardium paucispinosum sp. n. (Eucestoda: Hymenolepididae), parasite of Larus maculipennis (Aves: Laridae) in Mar del Plata, Argentina; with comments on Wardium semiductilis (Szidat, 1964) comb. n.
}

\author{
Juliana Beatríz Labriola ${ }^{1,2}$ and Delia Mabel Suriano ${ }^{1,2}$ \\ ${ }^{1}$ Laboratorio de Helmintología, Estación Costera J.J. Nágera, Departamento de Ciencias Marinas, Facultad de Ciencias Exactas y \\ Naturales, Universidad Nacional de Mar del Plata, Funes 3350, 7600 Mar del Plata, Buenos Aires, Argentina; \\ ${ }^{2}$ Consejo Nacional de Investigaciones Científicas y Técnicas (CONICET)
}

Key words: Eucestoda, Hymenolepididae, Wardium, Laridae, Argentina

\begin{abstract}
A new species Wardium paucispinosum (Eucestoda: Hymenolepididae) parasite from the intestine of Larus maculipennis (Lichtenstein) from Mar del Plata, Argentina is described. The distinctive features of the new species are: strobilar length $52.8 \mathrm{~mm} ; 10$ aploparaksoid rostellar hooks, 14 (12-17) $\mu \mathrm{m}$ long; ratio between cirrus pouch length and mature proglottid width (CPL/MPW) 0.38 (0.27-0.50); regular cylindrical evaginated cirrus, $90 \times 10 \mu \mathrm{m}$, with distal end without spines and proximal and medium thirds covered with spines $7 \mu \mathrm{m}$ long; simple tubular membranous vagina, $110 \times 10 \mu \mathrm{m}$, without sclerotised portions and sphincters; eggs fusiform, $77 \times 44 \mu \mathrm{m}$. Besides, Hymenolepis semiductilis Szidat, 1964, from the intestine of Larus dominicanus and L. maculipennis from Santa Fé, Argentina is transferred to the genus Wardium Mayhew, 1925 , based on the presence and shape of the rostellar hooks.
\end{abstract}

The study of the cestodes of the family Hymenolepididae Ariola, 1899 from Larus spp. from Argentina is restricted to investigations carried out by Szidat (1964). Recently a cestode belonging to the genus Wardium Mayhew, 1925 was collected from the intestine of Larus maculipennis (Lichtenstein) from Mar del Plata, Argentina. Wardium is a cosmopolitan genus parasitising birds from the orders Charadriiformes, Lariformes, Anseriformes, Podicipediformes and Passeriformes. The material collected from $L$. maculipennis was considered as a representative of a new species. The aim of this work is to describe precisely the new Wardium species and to propose a new combination for the species Hymenolepis semiductilis Szidat, 1964.

\section{MATERIALS AND METHODS}

From 1995 to 1998, 26 specimens of L. maculipennis caught in the outskirts of Mar del Plata city (38 $05^{\prime} \mathrm{S}$, $57^{\circ} 38^{\prime} \mathrm{W}$ ) in the district of General Pueyrredón, Buenos Aires Province, were examined. The birds were shot and carried to the laboratory where they were dissected and their viscera were examined under a dissecting microscope for cestodes. The gut was cut into five sections of equal length to determine the precise location of the parasites. From the gizzard to the cloaca this portions were named duodenum I, duodenum II, ileum I, ileum II and rectum. The cestodes collected were separated and transferred to physiological solution at $25^{\circ} \mathrm{C}$ to allow detachment, fixed in AFA, stained in hydrochloric carmine, dehydrated in alcohol solutions of increasing concentration, cleared with creosote and mounted in Canada balsam between microscope slide and cover slip. For histological sections, the cestodes were fixed in Bouin de Hollande, dehydrated, embedded in paraffin and stained in hematoxylin followed by eosin counterstain. Cestode anatomy was studied by means of a Leitz Laborlux light microscope and drawings were made by means of a drawing tube.

Cestode measurements were taking according to the scheme of Mas-Coma and Galán-Puchades (1991). Measurements of the first and last proglottid of each "type" are given. For the measurements of rostellar hooks the scheme proposed by Vaucher (1986) was adopted in which: a) total length, b) blade length, c) length of guard and d) handle length were measured; proportions suggested by Bona (1983) and adapted by Macko (1991) for hymenolepidids: blade length/ handle length and blade length/total length were calculated. For cestode taxonomical determination the criteria proposed by Czaplinski and Vaucher (1994) were followed. All measurements (means with ranges in parentheses) are in $\mu \mathrm{m}$, except as explicitly indicated in the text.

\section{RESULTS}

Wardium paucispinosum sp. $\mathrm{n}$.

Figs. 1-8

Description: Medium size worms, 52.8 (25-85) mm long. Strobila bearing about 1129 (662-1656) proglottids. Scolex conical, 220 (180-270) long by 150 (130-170) wide at suckers level (Fig. 1). Rostellum conical, armed with single crown of 10 aploparaksoid hooks of same size, inserted at same level (Fig. 2). Protruded rostellum 130 (100-500) long by 40 wide. 


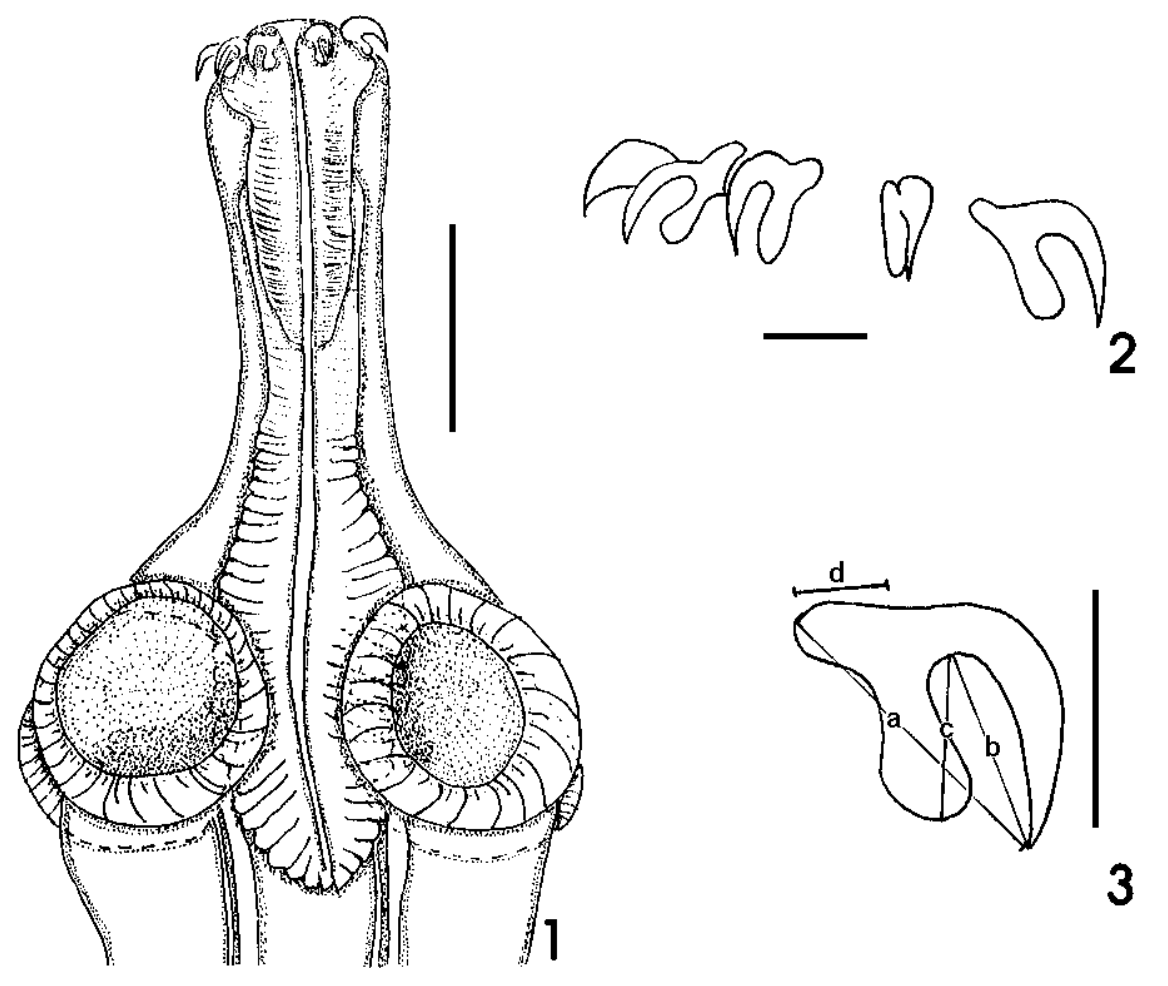

Figs. 1-3. Wardium paucispinosum sp. n. Fig. 1. Scolex of the holotype with everted rostellum. Fig. 2. Rostellar hook crown. Fig. 3. Rostellar hook. $a$ - total length; $b$ - blade length; $c$ - guard length; $d$ - handle length. Scale bars: Fig. $1=50 \mu \mathrm{m} ;$ Figs. 2,3 $=10 \mu \mathrm{m}$.

Rostellar pouch reaches posterior to beyond the posterior suckers, 150 (110-170) long by 60 (40-60) wide. Rostellar hooks (Fig. 3): a) total length 14 (1318), b) blade length 9 (8-10), c) garde length 7 (6-8) and d) handle length 4 (4-5); ratio blade length to handle length 2.25 (1.60-2.50); ratio blade length to total length 0.64 (0.44-0.77). Suckers four, unarmed, similar in size and shape, 50 (40-70) in minor diameter and 70 in major diameter. Neck 700 (430-1030) long by 100 (90130) wide. Proglottids symmetrical, craspedote, wider than long, with width-length ratio 7.14 (4.73-10.13) for young proglottids, $8.42(5.72-17.07)$ for premature proglottids, 5.38 (2.29-9.37) for mature proglottids, 7.85 (6.60-10.04) for post-mature proglottids, 4.80 (3.036.51) for pregravid proglottids and 3.84 (3.14-4.92) for gravid proglottids. In complete specimens 364 (215$500)$ young proglottids, $380 \quad(220-520)$ premature proglottids, 222 (122-400) mature proglottids, 15.5 (10-21) for post-mature proglottids, 167 (118-215) pregravid proglottids and 2 gravid proglottids. Pair of ventral osmoregulatory canals 21 (17-30) in diameter, pair of dorsal osmoregulatory canals 12 (7-17) in diameter. Genital ducts dorsal to osmoregulatory canals. Genital atrium muscular. Genital pores unilateral (on left proglottid margin in ventral view) opens in the middle third of proglottids margin.
Testes three, subspherical, 50 (30-70) in minor diameter and 60 (40-70) in major diameter, in triangle between osmoregulatory canals (lateral testes are slightly dorsal to median), in medial and posterior part of proglottis (Fig. 4). Large cirrus pouch, 180 (170-190) long by 50 wide, situated in anterior half of proglottids, and wall 14 (10-17) thick. Ratio between cirrus pouch length and mature proglottid width (CPL/MPW) 0.38 (0.27-0.50). Internal seminal vesicle 150 (130-170) long by 30 (20-30) wide occupying most of cirrus pouch; aporal end of internal seminal vesicle opens into external seminal vesicle. External seminal vesicle 40 (30-50) in minor diameter and 130 (70-210) in major diameter. This organ is dorsally directed, between aporal osmoregulatory canals and middle of proglottids, in posterior half of proglottids. Everted cirrus cylindrical, 90 (80-90) long, 10 (8-12) in diameter, armed in proximal and medium third but unarmed in distal third. Cirrus spines thin, 7 (6-8) long (Fig. 7).

Ovary trilobed, between osmoregulatory canals occupying whole width of the medial area, ventral to testes, dorsal to vitelline gland; 40 (30-50) in minor diameter and 210 (130-280) in major diameter (Fig. 5). Vitelline gland compact, suboval, median, postovarian, at posterior end of proglottids, 50 (30-70) in minor diameter and 80 (50-100) in major diameter. Vagina 

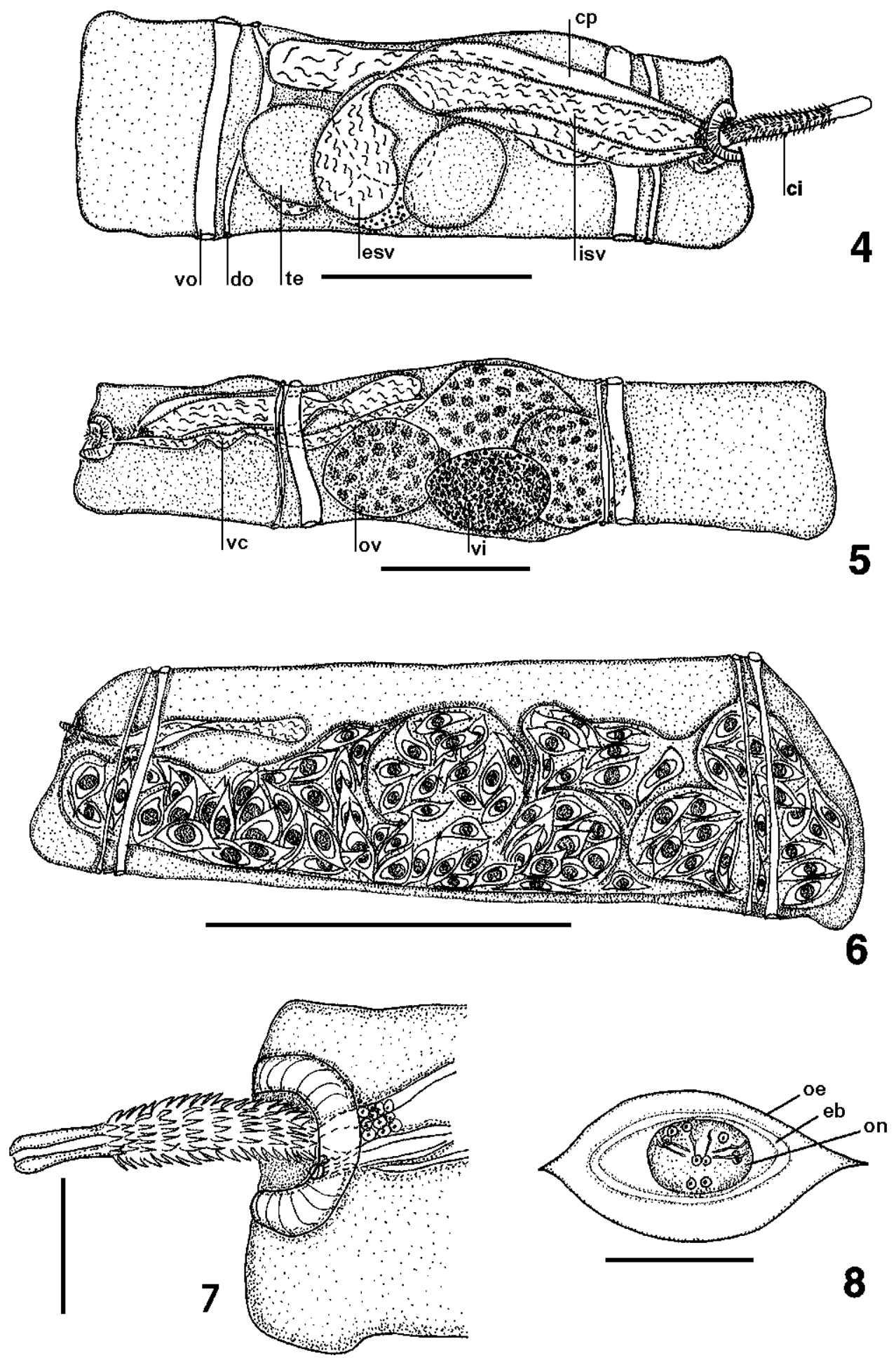

Figs. 4-8. Wardium paucispinosum sp. n. Fig. 4. Mature proglottid (dorsal view), holotype. Fig. 5. Mature proglottid (ventral view), holotype. Fig. 6. Gravid proglottid (ventral view) holotype. Fig. 7. Cirrus everted, genital atrium and vagina distal end. Fig. 8. Egg. Abbrevations: ci - cirrus; $c p$ - cirrus pouch; do - dorsal osmoregulatory canal; eb - embryophore; esv - external seminal vesicle; isv - internal seminal vesicle; oe - outer envelope; on - oncosphere; ov - ovary; te - testis; vc - vaginal canal; vi - vitellarium; vo - ventral osmoregulatory canal. Scale bars: Figs. $4,5=100 \mu \mathrm{m}$; Fig. $6=500 \mu \mathrm{m}$; Fig. $7=30 \mu \mathrm{m}$; Fig. $8=50 \mu \mathrm{m}$. 
Table 1. Comparative measurements (in micrometres) of species of Wardium from Larus gulls.

\begin{tabular}{|c|c|c|c|c|c|c|c|c|c|c|}
\hline $\begin{array}{c}\text { Species } \\
\text { Locality } \\
\text { Host } \\
\text { Authority }\end{array}$ & $\begin{array}{l}\text { Wardium } \\
\text { De la Manche } \\
\text { L. ridibundus } \\
\text { Deblock et }\end{array}$ & $\begin{array}{l}\text { irrosa } \\
\text { nal, France } \\
\text { d L. carnus } \\
\text { (1960) }\end{array}$ & $\begin{array}{r}\text { Wardiu } \\
\text { Tovačov, } \\
\text { L. ridil } \\
\text { Ryšavý and }\end{array}$ & $\begin{array}{l}\text { fusa } \\
\text { Moravia } \\
\text { ndus } \\
\text { tko (1992) }\end{array}$ & $\begin{array}{r}\text { Wardium } \\
\text { King George Is } \\
\text { L. domi }\end{array}$ & $\begin{array}{l}\text { towskii } \\
\text { d, Antarctica } \\
\text { anus } \\
\text { tas (1984) }\end{array}$ & $\begin{array}{l}\text { Wardium semiductilis } \\
\text { Santa Fé, Argentina } \\
\\
\text { L. dominicanus and } \\
\text { L. maculipennis } \\
\text { Present authors }\end{array}$ & $\begin{array}{l}\text { Wardiun } \\
\text { Mar del }\end{array}$ & $\begin{array}{l}\text { paucispino: } \\
\text { Plata, Argen } \\
\text { aculipennis }\end{array}$ & $\begin{array}{l}\text { sum } \\
\text { tina }\end{array}$ \\
\hline & minimum & maximum & minimum & maximum & minimum & maximum & mean & mean & minimum & maximum \\
\hline Total length (mm) & 110 & 140 & 19 & 92 & 70 & 90 & 65.5 & 52.8 & 25 & 85 \\
\hline Maximum width & 980 & 1000 & 800 & 1400 & 700 & & 900 & 970 & 420 & 1330 \\
\hline Rostelar hook shape & \multicolumn{2}{|c|}{ aploparaxoid } & \multicolumn{2}{|c|}{ aploparaxoid } & \multicolumn{2}{|c|}{ aploparaxoid } & echinorhynchoid & \multicolumn{3}{|c|}{ aploparaxoid } \\
\hline Rostelar hook number & 10 & & 10 & & 10 & & 8 to 10 & 10 & & \\
\hline Total length & 22 & 23 & 17 & 19 & 16 & 18 & 22 & 14 & 13 & 18 \\
\hline Blade length & 7 & 8 & & & & & 12 & 9 & 8 & 10 \\
\hline Handle length & & & & & & & 10 & 4 & 4 & 5 \\
\hline Garde length & & & & & & & 7 & 7 & 6 & 8 \\
\hline Testis number & 3 & & 3 & & 3 & & 3 & 3 & & \\
\hline Cirrus pouch length & 380 & & 200 & 230 & 180 & 217 & 330 & 180 & 170 & 190 \\
\hline width & 50 & & 20 & 30 & 37 & 45 & 30 & 50 & 50 & 50 \\
\hline CPL/MPW & 0.70 & & 0.23 & 0.46 & 0.50 & 0.75 & 0.85 & 0.38 & 0.27 & 0.50 \\
\hline Cirrus shape & cylindric & & fusiform & & other shape & & cylindric & cylindric & & \\
\hline Cirrus length & 500 & 630 & 48 & 60 & 16 & 23.5 & 10 & 90 & 80 & 90 \\
\hline Cirrus diameter & 8 & 10 & & & 4.5 & 5 & 5 & 10 & 8 & 12 \\
\hline Cirrus armature & totally spiny & & totally spiny & & partially spiny & & totally spiny & partially spiny & & \\
\hline Cirrus spines length & 3 & 4 & & & 1 & 1.5 & 2 & 7 & 6 & 8 \\
\hline Vagina length & & & & & & & 180 & 110 & 110 & 120 \\
\hline width & 10 & 10 & & & 10 & & 10 & 10 & 10 & 20.0 \\
\hline Uterus length (A) & & & & & 240 & 560 & & 270 & & \\
\hline$(\mathrm{P})$ & & & & & & & & 420 & & \\
\hline width (A) & & & & & & & & 1230 & & \\
\hline$(\mathrm{P})$ & & & & & & & & 1150 & & \\
\hline $\begin{array}{l}\text { Egg outer envelope } \\
\text { minor diam. }\end{array}$ & & & & & & & & 44 & & \\
\hline $\begin{array}{l}\text { minor diam. } \\
\text { major diam. }\end{array}$ & $\begin{array}{l}38 \\
50\end{array}$ & & $\begin{array}{l}32 \\
51\end{array}$ & $\begin{array}{l}46 \\
65\end{array}$ & 300 & & & 44 & 29 & $\begin{array}{l}54 \\
99\end{array}$ \\
\hline Oncosphere & 0 & & נו &  & 500 & & & 11 & 33 & 99 \\
\hline minor diam. & 30 & 35 & 20 & 32 & 20 & & & 20 & 8 & 25 \\
\hline major diam. & & & 27 & 44 & 30 & & & 35 & 12 & 58 \\
\hline
\end{tabular}

CPL - cirrus pouch length; MPW - mature proglottid width 
tubular, without sclerotised portions and sphincters, membranous, 110 (110-120) long by 10 (10-20) wide with distal end opening into genital atrium posteriorly to male pore; proximal end opening into elongated seminal receptacle. Seminal receptacle 90 (80-110) long by 32 (20-40) wide, transverse, oblique, in anterior half of proglottids, reaching aporal osmoregulatory canals, ventral to cirrus pouch. Uterus sacciform 270-420 long by $1140-1230$ wide, in gravid proglottids, including 150-300 eggs, occupies practically complete proglottids Fig. 6). Eggs fusiform; outer envelope 44 (29-54) in minor diameter, 77 (33-99) in major diameter. Oncosphere 20 (8-25) in minor diameter and 35 (12-58) in major diameter. Embryonic hooks central pair 9 (8-10) long, lateral pair hooks 12 long (Fig. 8).

T y p e host: Larus maculipennis (Lichtenstein, 1823).

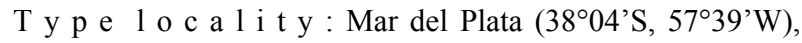
Argentina.

Site of infection: ileum I, II.

Prevalence: $7.7 \%$.

Mean intensity: 4 .

$\mathrm{M}$ a t e ri a $1 \mathrm{stud}$ i e d : 8 specimens (measurements based on 6 specimens).

De p o s it i o n of ty p e s: Holotype, Museo Argentino de Ciencias Naturales "Bernardino Rivadavia" (Avenida A. Gallardo 470, 1405 Capital Federal, Buenos Aires, Argentina.), helminthological collection No. 380/1, 380/2. Two paratypes, Institute of Parasitology, Academy of Sciences of the Czech Republic, Branišovská 31, 37005 České Budějovice, Czech Republic, No. C-311.

E t y m o 1 o g y : The species name paucispinosum (Latin; semispinous) refers to the partial cirrus armature.

\section{DISCUSSION}

The new hymenolepidid described above belongs to the genus Wardium Mayhew, 1925 because of the following characteristics: rostellum retractable or invaginable with single crown of 10 aploparaksoid or echinorhynchoid hooks; suckers unarmed; proglottids craspedote; numerous internal longitudinal muscle bundles; genital ducts dorsal to osmoregulatory canals; three testes per proglottid, in row or in triangle; armed cirrus; absence of internal accessory sac and cirrus stylet; ovary lobed and median; vitellarium compact or slightly lobed, postovarian; seminal receptacle well developed; sacciform uterus; oval eggs with oval or filamentous external covering.

Wardium paucispinosum resembles Wardium cirrosa (Deblock, Capron et Rose, 1960), Wardium fusa (Krabbe, 1869) Spasskii, 1961 (in Ryšavý and Sitko 1992), Wardium arctowskii (Jarecka et Ostas, 1984) and Wardium semiductilis (Szidat, 1964) (Table 1).

Wardium paucispinosum may be distinguished from $W$. cirrosa by the following characters: a) shorter rostellar hooks total length (12-17 vs. 22-24); b) longer blade rostellar hook length (10-12 vs. $7-8)$; c) shorter cirrus length (80-90 vs. 500-630); d) spines in the proximal and medium third of the cirrus vs. cirrus totally spiny; e) longer cirrus spine length (6-8 vs. 3-4).

The anatomical characters that distinguish $W$. paucispinosum from $W$. fusa are: a) slightly shorter rostellar hook total length (12-17 vs. 17-19); b) cylindrical cirrus shape vs. fusiform cirrus shape; c) spines in the proximal and medium third of the cirrus vs. cirrus totally spiny.

Wardium paucispinosum may be distinguished from $W$. arctowskii from Larus dominicanus of South Shetland, Antarctica by the following characters: a) testes in triangle vs. testes in horizontal row; b) longer everted cirrus, 90 (80-90) vs. 16-23.5; c) cirrus shape cylindrical vs. composed shape: basal portion broadened, mid portion with club-shaped swelling and terminal portion cylindrical; d) numerous cirrus spine rows in proximal and middle cirrus thirds vs. three cirrus spine rows in the middle third; e) longer cirrus spines, 7 (6-8) vs. 1-1.5; f) vagina distal end membranous and cylindrical without chitinoid ornamentations vs. vagina distal end cup-shaped with longitudinal grooves chitinoid ornamentation; g) shorter egg outer envelope maximum diameter 77 (33-99) vs. 300; h) shorter embryonic hook total length, 8-12 vs. 12-14.

Szidat (1964) created the species Hymenolepis semiductilis, a parasite of Larus dominicanus and $L$. maculipennis from Santa Fé, Argentina. In the course of this study, the holotype No. 50/1 and the paratype No. $50 / 2$ described by Szidat were examined. It was apparent that the anatomical characteristics of the cestode did not match actually those defining the genus Hymenolepis Weinland, 1858, according to Czaplinski and Vaucher (1994). According to Szidat's description and our revision of the holotype, the cestode shows a rostellum and a crown of 10 echinorhynchoid hooks, compatible with the genus Wardium. This cestode is therefore transferred to the genus Wardium as Wardium semiductilis (Szidat, 1964) comb. n. Wardium paucispinosum may be separated from $W$. semiductilis by the shape of the rostellar hooks (aploparaksoid vs. echinorhynchoid), the evaginated cirrus length (90 vs. $10)$ and the cirrus spines length (7 vs. 2$)$. The cirrus in the $W$. semiductilis holotype is invaginated; therefore, cirrus spine distribution could not be determined.

In Argentina, the genus Wardium in Larus gulls is now represented by two species: $W$. semiductilis and $W$. paucispinosum.

Acknowledgements. We are grateful to CONICET for the financial assistance, to Dr. T. Stadler, curator of the helminthological collection of Museo Argentino de Ciencias Naturales "Bernardino Rivadavia" for the loan of the Hymenolepis semiductilis Szidat, 1964 holotype No. 50/1 and paratype No. 50/2, to Dr. A. Bachmann for comments on scientific nomenclature and to Jorge Paoloni for shooting the gulls. 


\section{REFERENCES}

BONA F.V. 1983: Variability and growth of cestodes premises to a biometric analysis. Dendrouterina pilherodiae meridionalis n. subsp., parasite of Egretta alba (Ciconiiformes) in Argentina and redescription of the type D. pilherodiae Mahon, 1956 (Cestoda, Dilepididae). Part. I. Riv. Parassitol. 44: 279-297.

CZAPLINSKI B., VAUCHER C. 1994: Family Hymenolepididae Ariola, 1899. In: L. F. Khalil, A. Jones and R. A. Bray (Eds.), Keys to the Cestode Parasites of Vertebrates. CAB International, Wallingford, UK, pp. 595-672.

DEBLOCK S., CAPRON A., ROSE F. 1960: Redescription d'Hymenolepis (nec Aploparaksis) cirrosa (Krabbe, 1869) (Cestoda, Hymenolepididae). Bull. Soc. Zool. Fr. 85: 5867.

JARECKA L., OSTAS J. 1984: Hymenolepis arctowskii sp.n. (Cestoda, Hymenolepididae) from Larus dominicanus Licht. of the Antarctic. Acta Parasitol. Pol. 29: 189-196.

MACKO J.K. 1991: A revision of the genus Dicranotaenia (Cestoda: Hymenolepididae). I. New data on the type specimens of Dicranotaenia querquedula (Fuhrmann, 1921) and D. parisaccata (Shepard, 1943) plus an assessment of the original description of $D$. coronula (Dujardin, 1845). Syst. Parasitol. 18: 51-58.
MAS-COMA S., GALAN-PUCHADES M.T. 1991: A methodology for the morphoanatomic and systematic study of the species of the family Hymenolepididae Railliet et Henry, 1909 (Cestoda: Cyclophyllidea). Res. Rev. Parasitol. 51: 139-173.

RYŠAVÝ B., SITKO J. 1992: Tapeworms (Cestoda) of birds from Moravia (Czech and Slovak Federal Republic). Př́rodovědné práce ústavů Československé akademie věd v Brně 26: 1-93.

SPASSKII A.A. 1961: Breve revisione di Hymenolepididae. Parte seconda. Parassitologia 3: 179-198.

SZIDAT L. 1964: Comparative helminthological investigation on the Argentine large gulls Larus marinus dominicanus Lichtenstein and Larus ridibundus maculipennis Lichtenstein including new observations concerning species formation in parasites. Z. Parasitenkd. 24: 351414.

VAUCHER C. 1986: Helminthes parasites du Paraguay. XI: Hymenolepididae (Cestoda) parasites de Chiroptères Molossidae, avec description de deux espèces nouvelles. Rev. Suisse Zool. 93: 393-407.

Accepted 23 February 2000 